\title{
Interjurisdictional Spillovers, Decentralized Policymaking and the Elasticity of Capital Supply
}

\author{
Thomas Eichner \\ Marco Runkel
}

CESIFO WORKING PAPER NO. 3214

CATEgory 1: Public FinANCE

OCTOBER 2010

An electronic version of the paper may be downloaded

- from the SSRN website:

- from the RePEc website:

- from the CESifo website:

www.SSRN.com

Www.RePEc.org

www.CESifo-group.org/wp 


\title{
Interjurisdictional Spillovers, Decentralized Policymaking and the Elasticity of Capital Supply
}

\begin{abstract}
This paper points to the important role which the elasticity of aggregate capital supply with respect to the net rate of return to capital plays for the efficiency of policymaking in a decentralized economy with mobile capital and spillovers among jurisdictions. In accordance with previous studies, we show that under the assumption of a fixed capital supply (zero capital supply elasticity) the decentralized policy choice is optimal. If the capital supply elasticity is strictly positive, however, capital tax rates are inefficiently low in the decentralized equilibrium.
\end{abstract}

JEL-Code: H23, H77, Q58.

Keywords: decentralized policymaking, spillovers, capital supply elasticity.

\author{
Thomas Eichner \\ Department of Economics \\ University of Hagen \\ Universitätsstrasse 41 \\ 58097 Hagen \\ Germany \\ thomas.eichner@fernuni-hagen.de
}

\author{
Marco Runkel \\ Faculty of Economics and Management \\ University of Magdeburg \\ Postbox 4120 \\ 39016 Magdeburg \\ Germany \\ marco.runkel@ovgu.de
}

September 15, 2010

We would like to thank David Wildasin for useful comments. The usual disclaimer applies. 


\section{Introduction}

A key question in the Fiscal Federalism literature is whether decentralized policymaking in an economy with spillovers among jurisdictions leads to an efficient outcome (see e.g. Oates, 1974). A striking example where this question is of particular importance is the current debate on global warming. The failure of the Copenhagen Summit in late 2009 has impressively shown that centralized solutions to the climate change problem are hardly realizable. One might thus want to know whether a decentralized policy approach, where each country chooses its own climate policy without coordinating it with the climate policy of other countries, gives hope for an efficient policy outcome. Further important examples of decentralized decision making in the presence of interjurisdictional spillover effects can be found in the decentralized provision of education and infrastructure.

At first glance, it is hardly imaginable that decentralized policymaking can ever be optimal. It is not only the very existence of spillovers which causes doubt. Also the policy instruments themselves create (policy) externalities on other jurisdictions. Despite this presumption against the efficiency of decentralized policymaking, the previous literature provides several studies in which decentralization leads to an undistorted policy choice. An important example is given by Oates and Schwab (1988) who argue that the choice of capital tax rates in an economy with identical jurisdictions, mobile capital and local pollution may indeed be efficient. In a remarkable current paper, Ogawa and Wildasin (2009) extend the analysis to account for transboundary pollution (spillovers) and asymmetric countries, and still get the efficiency result. In their model emissions and, thus, the extent of spillovers generated by a jurisdiction is proportional to capital employed in this jurisdiction. The choice of capital tax rates is then distorted by the jurisdictions' incentive for tax competition and by the jurisdictions' ignorance of spillover effects. But the key argument is that both distortions just neutralize each other and thereby lead to efficient capital tax rates.

Our paper contributes to this literature and points to the important role which the elasticity of aggregate capital supply with respect to the net rate of return to capital plays for the efficiency of decentralized policymaking. In accordance with the previous literature, we show that under a fixed capital supply (zero capital supply elasticity) the decentralized policy choice is indeed optimal. If the capital supply elasticity is strictly positive, however, capital tax rates are inefficiently low in the decentralized equilibrium. The rationale is that, with a positive capital supply elasticity, a capital tax rate increase in one jurisdiction lowers 
the net return to capital and, thus, aggregate capital supply as well as total emissions in the whole economy. For that reason the distortion of capital taxes due to the environmental spillover effects is smaller than in case with fixed capital supply and no longer large enough to compensate the distortion due to the tax competition incentive of the jurisdictions.

The paper is organized as follows. Section 2 describes the basic model assumption. In Section 3 we characterize the efficiency properties of decentralized policymaking, and Section 4 briefly concludes by discussing the relevance of a positive capital supply elasticity.

\section{Model}

Firms. We use a simplified version of the Ogawa and Wildasin (2009) model $^{1}$ and extend it to appropriately deal with elastic capital supply. Consider an economy with $n$ jurisdictions. Jurisdiction indices are $i, j \in\{1, \ldots, n\}$ with $i \neq j$. In jurisdiction $i$ there is a representative firm that employs $k_{i}$ units of capital in order to produce $F\left(k_{i}\right)$ units of an output good whose price is normalized to one. The production function is increasing and concave, i.e. $F^{\prime}>0$ and $F^{\prime \prime}<0$. Each unit of capital is rented on the economy-wide capital market at the net return to capital denoted by $\rho>0$. Since jurisdiction $i$ levies a unit tax on capital at rate $t_{i}$, after-tax profit of the firm located in jurisdiction $i$ reads

$$
\pi_{i}=F\left(k_{i}\right)-\left(\rho+t_{i}\right) k_{i}
$$

The first-order condition of profit maximization is

$$
F^{\prime}\left(k_{i}\right)-t_{i}=\rho
$$

It equalizes the after-tax return to capital across countries.

Households. Each jurisdictions is populated by a representative household who lives for two periods. In the first period, jurisdiction $i$ 's resident has an endowment $\bar{k}$ of first period income that can either be spent for first-period consumption at rate $x_{i}^{1}$ or saved at rate $s_{i}=\bar{k}-x_{i}^{1}$. In the second period, the resident receives capital income $(1+\rho) s_{i}$ and profit income $\pi_{i}$ earned in her jurisdiction, less a lump sum tax $\tau_{i}$ levied by jurisdiction $i$. The

\footnotetext{
${ }^{1}$ The simplification is that we focus on the case of perfectly symmetric countries, while the analysis of Ogawa and Wildasin (2009) allows for country asymmetries. Abstracting from such asymmetries is suitable for our purposes since we are interested in the role of the capital supply elasticity.
} 
second-period budget is $x_{i}^{2}=(1+\rho) s_{i}+\pi_{i}-\tau_{i}$ where $x_{i}^{2}$ denotes second-period consumption. Beside private consumption, utility of jurisdiction $i$ 's resident is affected by the quantity $g_{i}$ of a locally provided public good and by pollution $e_{i}$. The utility function is given by

$$
u_{i}=U\left(x_{i}^{1}\right)+x_{i}^{2}+V\left(g_{i}, e_{i}\right)=U\left(\bar{k}-s_{i}\right)+(1+\rho) s_{i}+\pi_{i}-\tau_{i}+V\left(g_{i}, e_{i}\right) .
$$

The subutility functions $U$ and $V$ are assumed to be concave and satisfy $U^{\prime}>0, V_{g}>0$ and $V_{e}<0$. Maximizing utility (3) with respect to savings $s_{i}$ gives $U^{\prime}\left(\bar{k}-s_{i}\right)-1-\rho=0$. This condition determines savings as a function of the interest rate $\rho$, i.e. $s_{i}=S(\rho)$. The derivative $S^{\prime}(\rho)=-1 / U^{\prime \prime}>0$ serves as approximation for the capital supply elasticity $\varepsilon:=\rho S^{\prime} / S$. For notational convenience, we do not replace $S^{\prime}$ by an expression containing $\varepsilon$, but instead use $S^{\prime}$ to distinguish the case of a positive elasticity $\left(S^{\prime}>0\right.$ and $\varepsilon>0$ ) from the case of a zero elasticity, which is obtained by setting $S^{\prime} \equiv \varepsilon \equiv 0$.

Capital Market. Capital is perfectly mobile. On the economy-wide capital market, capital demand of firms meets capital supply of households. The equilibrium condition is

$$
\sum_{i=1}^{n} k_{i}=n S(\rho) .
$$

Equations (2) and (4) determine the equilibrium capital allocation $\left\{k_{i}\right\}_{i=1}^{n}$ and the net return to capital $\rho$ as functions of the tax rates $\left\{t_{i}\right\}_{i=1}^{n}$. Totally differentiating and then applying the symmetry property $t_{i}=t$ and $k_{i}=S(\rho)$ yields the comparative static results

$$
\begin{gathered}
\frac{\partial \rho}{\partial t_{i}}=-\frac{1}{n\left(1-F^{\prime \prime} S^{\prime}\right)}<0, \frac{\partial k_{i}}{\partial t_{i}}=\frac{n-1-n F^{\prime \prime} S^{\prime}}{n\left(1-F^{\prime \prime} S^{\prime}\right) F^{\prime \prime}}<0, \quad \frac{\partial k_{j}}{\partial t_{i}}=-\frac{1}{n\left(1-F^{\prime \prime} S^{\prime}\right) F^{\prime \prime}}>0 \\
\frac{\partial k_{i}}{\partial t_{i}}+(n-1) \frac{\partial k_{j}}{\partial t_{i}}=-\frac{S^{\prime}}{1-F^{\prime \prime} S^{\prime}}<0
\end{gathered}
$$

As shown in (5), a unilateral increase in one jurisdiction's capital tax rate reduces investment in that jurisdiction and increases investment in all other jurisdictions via a decline in the net return to capital. The decisive difference of our approach to the case with fixed capital supply is that, according to (6), the increase in one jurisdiction's tax rate lowers total capital supply and, thus, total investment. Investment in the tax-increasing jurisdiction therefore falls by more than it does in the presence of a fixed capital supply. Formally, this is represented by the additional term $-n F^{\prime \prime} S^{\prime}$ in the numerator of $\partial k_{i} / \partial t_{i}$ in equation (5).

Emissions. Each unit of capital employed in jurisdiction $i$ generates $\alpha>0$ units of emissions in jurisdiction $i$ and $\beta \alpha$ units of emissions in jurisdiction $j$. The parameter 
$\beta \in[0,1]$ reflects the degree of interjurisdictional spillovers. In case of $\beta=0$ we have local pollution, while $\beta>0$ reflects transboundary pollution. The extreme case of $\beta=1$ approximates global pollution since each unit of emissions causes the same pollution in all jurisdictions. Total pollution in jurisdiction $i$ is given by

$$
e_{i}=\alpha k_{i}+\beta \alpha \sum_{j \neq i}^{n} k_{j}
$$

Differentiating (7) and taking into account (5) and (6) yields

$$
\begin{gathered}
\frac{\partial e_{i}}{\partial t_{i}}=\frac{\alpha\left[(1-\beta)(n-1)-n F^{\prime \prime} S^{\prime}\right]}{n\left(1-F^{\prime \prime} S^{\prime}\right) F^{\prime \prime}}<0, \quad \frac{\partial e_{j}}{\partial t_{i}}=\frac{\alpha\left[\beta-1-\beta n F^{\prime \prime} S^{\prime}\right]}{n\left(1-F^{\prime \prime} S^{\prime}\right) F^{\prime \prime}} \gtreqless 0, \\
\frac{\partial e_{i}}{\partial t_{i}}+(n-1) \frac{\partial e_{j}}{\partial t_{i}}=-\frac{\alpha[1+\beta(n-1)] S^{\prime}}{1-F^{\prime \prime} S^{\prime}}<0 .
\end{gathered}
$$

A tax rate increase in jurisdiction $i$ induces a relocation of capital and, thus, emissions from jurisdiction $i$ to all other jurisdictions. As a consequence, pollution in jurisdiction $i$ falls if the 'spill back' effect is not perfect, i.e. pollution is not global ( $\beta \in[0,1[)$. Moreover, the increase in jurisdiction $i$ 's tax rate reduces total capital supply and thereby total emissions according to (9). Hence, as shown by (8), pollution in jurisdiction $i$ falls upon a tax rate increase in jurisdiction $i$, even if pollution is global $(\beta=1)$. This property is an important difference to the world with fixed capital supply $\left(S^{\prime} \equiv 0\right)$. It also explains why, according to (8), the effect of jurisdiction $i$ 's tax rate on pollution in jurisdiction $j$ is ambiguous. With a fixed capital supply $\left(S^{\prime} \equiv 0\right)$, the relocation of capital and emissions raises (if $\beta \in[0,1[$ ) or leaves unchanged (if $\beta=1$ ) pollution in jurisdiction $j$. However, if capital supply is elastic $\left(S^{\prime}>0\right)$ and if the spillovers are strictly positive $\left.\left.(\beta \in] 0,1\right]\right)$, jurisdiction $j$ benefits from the additional reduction in investment and emissions in the tax-increasing jurisdiction $i$. Formally, this effect is reflected by $-\beta n F^{\prime \prime} S^{\prime}$ in the numerator of $\partial e_{j} / \partial t_{i}$ in equation (8). Put differently, the more elastic capital supply, the lower is ceteris paribus the increase of pollution in jurisdiction $j$ upon a tax rate increase in jurisdiction $i$. This effect will turn out to be the driving force behind our main insights derived below.

Governments. The government of jurisdiction $i$ chooses the lump sum tax $\tau_{i}$ and the capital tax $t_{i}$ in order to maximize its resident's welfare (3). In so doing, it takes into account $s_{i}=S(\rho),(1),(2)$ and (4)-(9). Moreover, it is restricted by the budget constraint

$$
g_{i}=t_{i} k_{i}+\tau_{i}
$$


where we assumed that the output of firms can be transformed one-to-one into the public good. Each government treats the policy variables of the other governments as given, so we consider a Nash policy game in the lump sum tax and the capital tax.

\section{Decentralized Equilibrium}

Focusing on the symmetric equilibrium with $\tau_{i}=\tau^{*}$ and $t_{i}=t^{*}$, the first-order conditions of jurisdiction $i$ 's welfare maximization are $\mathrm{d} u_{i} / \mathrm{d} \tau_{i}=0$ and $\mathrm{d} u_{i} / \mathrm{d} t_{i}=0$ or, equivalently

$$
V_{g}=1, \quad t^{*}=-\frac{\alpha\left[(1-\beta)(n-1)-n F^{\prime \prime} S^{\prime}\right] V_{e}}{n-1-n F^{\prime \prime} S^{\prime}} .
$$

The first condition in (11) shows that the lump sum tax is set such that the Samuelson condition for the optimal provision of public goods is satisfied. The second condition gives the equilibrium capital tax rate, which deviates from the full marginal damage a unit of emissions causes in the whole economy, i.e. $t^{*} \neq-\alpha[1+\beta(n-1)] V_{e}$. This deviation is true independent of whether we consider fixed or elastic capital supply.

To assess the efficiency properties of the Nash equilibrium we determine the policy externalities, i.e. the effect of jurisdiction $i$ 's tax rate on welfare in jurisdiction $j$. If the externality is positive (negative), then starting from the symmetric Nash equilibrium and marginally increasing the tax rates of all jurisdictions by the same amount leads to a Pareto improvement (deterioration) and, thus, the tax rates are inefficiently low (high). For a zero externality, the Nash equilibrium is efficient. Differentiating $u_{j}$ from (3) with respect to $\tau_{i}$ and $t_{i}$ and taking into account (1), (2), (3)-(10) and the symmetry assumption yields

$$
\frac{\mathrm{d} u_{j}}{\mathrm{~d} \tau_{i}}=0, \quad \frac{\mathrm{d} u_{j}}{\mathrm{~d} t_{i}}=\mathrm{FE}+\mathrm{EE},
$$

with

$$
\mathrm{FE}=V_{g} \frac{\partial g_{j}}{\partial t_{i}}=-\frac{t^{*} V_{g}}{n\left(1-F^{\prime \prime} S^{\prime}\right) F^{\prime \prime}}, \quad \mathrm{EE}=V_{e} \frac{\partial e_{j}}{\partial t_{i}}=-\frac{\alpha\left(\beta-1-\beta n F^{\prime \prime} S^{\prime}\right) V_{e}}{n\left(1-F^{\prime \prime} S^{\prime}\right) F^{\prime \prime}}
$$

According to (12), the equilibrium lump sum tax is efficient since the associated externality is zero. This is consistent with the Samuelson rule in (11). The cross-jurisdictional effect of the capital tax rate can be decomposed into two subexternalities. When jurisdiction $i$ raises its capital tax rate, it does not take into account that capital flights out and thereby improves the tax base and public goods provision in jurisdiction $j$. This effect is reflected by the fiscal externality FE which is positive and points to inefficiently low tax rates. Second, if 
jurisdiction $i$ raises its capital tax rate, the associated relocation of capital changes pollution in jurisdiction $j$. This effect is captured by the environmental externality EE. Since $\partial e_{j} / \partial t_{i}$ from (8) is ambiguous, the environmental externality is indeterminate in sign.

The decisive question is whether the sum of externalities is positive, negative or zero. Adding FE and EE and using the equilibrium conditions (11) yields

$$
\frac{\mathrm{d} u_{j}}{\mathrm{~d} t_{i}}=\mathrm{FE}+\mathrm{EE}=-\frac{\alpha \beta n S^{\prime} V_{e}}{n-1-n F^{\prime \prime} S^{\prime}} .
$$

From expression (14) we immediately obtain the following

Proposition. Suppose the Nash policy game attains a symmetric equilibrium and pollution is transboundary, i.e. $\beta \in] 0,1]$. If capital supply is fixed $\left(S^{\prime} \equiv 0\right)$, then the equilibrium capital tax rate $t^{*}$ is efficient. In contrast, if capital supply is elastic $\left(S^{\prime}>0\right)$, then the equilibrium capital tax rate $t^{*}$ is inefficiently low.

The first part of the Proposition replicates the efficiency result of Ogawa and Wildasin (2009). It is a remarkable result since, with mobile capital, the tax competition incentive of jurisdictions actually distorts the capital tax rate downwards. In the presence of interjurisdictional spillovers, however, the capital tax rate is distorted for a second reason. Each jurisdiction does not fully internalize the economy-wide environmental damage caused by its firm (remember $t^{*}$ from (11)). The important contribution of Ogawa and Wildasin (2009) is to show that both distortions just neutralize each other, so equilibrium capital tax rates are efficient. In terms of externalities, with fixed capital supply the environmental externality EE is negative and just outweighs the positive fiscal externality FE.

The contribution of our analysis is the second part of the Proposition, which shows that with elastic capital supply the efficiency result does not longer hold. The driving force behind this result is the impact of the capital supply elasticity (approximated by $S^{\prime}$ ) on pollution. As argued in the discussion of (8), the larger the capital supply elasticity, the lower is the increase in jurisdiction $j$ 's pollution upon an increase in jurisdiction $i$ 's capital tax rate and, thus, the smaller is the distortion of the capital tax rate due to the ignored environmental spillover effects. Hence, if the capital supply elasticity is positive, the environmental distortion is no longer large enough to compensate the tax competition distortion. Put differently, with a positive capital supply elasticity the environmental externality EE in (13) is smaller in absolute terms than the fiscal externality FE in (13), hence the equilibrium capital tax rates become inefficiently low. 
Two remarks are in order. First, it is the interaction of the positive capital supply elasticity $\left(S^{\prime}>0\right)$ and the existence of spillovers $\left.\left.(\beta \in] 0,1\right]\right)$ which causes the inefficiency. With local pollution $(\beta=0)$, the equilibrium capital tax rate is efficient even if capital supply is elastic. The reason why we need strictly positive spillovers is that the reduction of pollution in jurisdiction $j$, which causes the decisive decrease in the environmental externality, comes from the negative effect of the capital supply elasticity on investment and emissions in jurisdiction $i$, and this effect translates into a fall of pollution in jurisdiction $j$ only if spillovers are strictly positive. Remember our discussion of equation (8). Second, an increase in the number of jurisdictions tends to aggravate the distortion of capital tax rates. From (14) we see that the policy externality which jurisdiction $i$ inflicts on one single other jurisdiction becomes smaller as $n$ increases. But the number of jurisdictions which are harmed by the ignorance of jurisdiction $i$ increases. Hence, decisive is the sum of externalities inflicted on all other jurisdictions, $(n-1)\left(\partial u_{j} / \partial t_{i}\right)$, and this sum is increasing in $n$. Roughly speaking, in economies with many relatively small jurisdictions the inefficiency therefore tends to be more severe than in economies with few relatively large jurisdictions.

\section{Relevance}

The assumption of a positive capital supply elasticity has intensively been used in the theoretical literature. An important example is the analysis of Keen and Kotsogiannis (2002) who point out that the relation of horizontal and vertical fiscal externalities in federal states crucially depends on the capital supply elasticity. Empirically, the evidence is mixed. A much-cited estimate for the capital supply elasticity is 0.4 found by Boskin (1978). Bernheim (2002) argues that the estimates range from values close to zero up to 0.4, whereas Gylfason (1993) reports estimated values significantly larger than one. Taking this mixed observations literally, our analysis can best be understood as complementing the previous literature. While the efficiency result of e.g. Ogawa and Wildasin (2009) is relevant for all economies where the capital supply elasticity has been found to be negligible, our analysis suggests that for economies with significantly positive capital supply elasticities it cannot be expected that decentralized policymaking yields an efficient outcome. 


\section{References}

Bernheim, D. (2002), Taxation and Saving, in: Auerbach, A.J. and M. Feldstein (Eds.), Handbook of Public Economics Vol. 3, 1173-1249.

Boskin, M.J. (1978), Taxation, Saving, and the Rate of Interest, Journal of Political Economy 86, S3-27.

Gylfason, T. (1993), Optimal Saving, Interest Rates, and Endogenous Growth, Scandinavian Journal of Economics 95, 517-533.

Keen, M.J. and C. Kotsogiannis (2002), Does Federalism Lead to Excessively High Taxes?, American Economic Review 92, 363-370.

Oates, W.E. (1974), Fiscal Federalism, New York: Harcourt Brace Jovanovich.

Oates, W.E. and R.M. Schwab (1988), Economic Competition Among Jurisdictions: Efficiency Enhancing or Distortion Inducing, Journal of Public Economics 35, 333-354.

Ogawa, H. and D.E. Wilson (2009), Think Locally, Act Locally: Spillovers, Spillbacks, and Efficient Decentralized Policymaking, American Economic Review 99, 1206-1217. 


\section{CESifo Working Paper Series}

for full list see www.cesifo-group.org/wp

(address: Poschingerstr. 5, 81679 Munich, Germany, office@cesifo.de)

3152 Lorenzo C. G. Pozzi, Casper G. de Vries and Jorn Zenhorst, World Equity Premium Based Risk Aversion Estimates, August 2010

3153 Volker Grossmann, Thomas M. Steger and Timo Trimborn, Dynamically Optimal R\&D Subsidization, August 2010

3154 Alexander Haupt, Tim Krieger and Thomas Lange, A Note on Brain Gain and Brain Drain: Permanent Migration and Education Policy, August 2010

3155 António Afonso and Christophe Rault, Long-run Determinants of Sovereign Yields, August 2010

3156 Franziska Tausch, Jan Potters and Arno Riedl, Preferences for Redistribution and Pensions. What can we Learn from Experiments?, August 2010

3157 Martin Kolmar and Andreas Wagener, Inefficient Group Organization as Optimal Adaption to Dominant Environments, August 2010

3158 Kai Carstensen, Klaus Wohlrabe and Christina Ziegler, Predictive Ability of Business Cycle Indicators under Test: A Case Study for the Euro Area Industrial Production, August 2010

3159 Horst Rottmann and Timo Wollmershäuser, A Micro Data Approach to the Identification of Credit Crunches, August 2010

3160 Philip E. Graves, Appropriate Fiscal Policy over the Business Cycle: Proper Stimulus Policies Can Work, August 2010

3161 Michael Binder and Marcel Bluhm, On the Conditional Effects of IMF Program Participation on Output Growth, August 2010

3162 Michael Binder, Qianying Chen, and Xuan Zhang, On the Effects of Monetary Policy Shocks on Exchange Rates, August 2010

3163 Felix J. Bierbrauer, On the Optimality of Optimal Income Taxation, August 2010

3164 Nikolaus Wolf, Europe’s Great Depression - Coordination Failure after the First World War, September 2010

3165 Dan Kovenock and Brian Roberson, Conflicts with Multiple Battlefields, September 2010

3166 Jean-Pierre Ponssard and Catherine Thomas, Capacity Investment under Demand Uncertainty. An Empirical Study of the US Cement Industry, 1994-2006, September 2010 
3167 Jørgen Juel Andersen, Jon H. Fiva and Gisle James Natvik, Voting when the Stakes are High, September 2010

3168 Michael Hoel, Is there a Green Paradox?, September 2010

3169 Scott Alan Carson, Nineteenth Century US African-American and White Female Statures: Insight from US Prison Records, September 2010

3170 Gil S. Epstein, Yosef Mealem and Shmuel Nitzan, Political Culture and Discrimination in Contests, September 2010

3171 Sara Fisher Ellison, Jeffrey Greenbaum and Wallace P. Mullin, Diversity, Social Goods Provision, and Performance in the Firm, September 2010

3172 Silvia Dominguez-Martinez, Randolph Sloof and Ferdinand von Siemens, Monitoring your Friends, not your Foes: Strategic Ignorance and the Delegation of Real Authority, September 2010

3173 Marcus Dittrich and Beate Schirwitz, Union Membership and Employment Dynamics: A Note, September 2010

3174 Francesco Daveri, Paolo Manasse and Danila Serra, The Twin Effects of Globalization - Evidence from a Sample of Indian Manufacturing Firms, September 2010

3175 Florian Blöchl, Fabian J. Theis, Fernando Vega-Redondo and Eric O’N. Fisher, Which Sectors of a Modern Economy are most Central?, September 2010

3176 Dag Morten Dalen, Marilena Locatelli and Steinar Strøm, Longitudinal Analysis of Generic Substitution, September 2010

3177 Armin Falk, Stephan Meier and Christian Zehnder, Did we Overestimate the Role of Social Preferences? The Case of Self-Selected Student Samples, September 2010

3178 Christian Fahrholz and Cezary Wójcik, The Bail-Out! Positive Political Economics of Greek-type Crises in the EMU, September 2010

3179 Klaus Abberger and Wolfgang Nierhaus, The Ifo Business Cycle Clock: Circular Correlation with the Real GDP, September 2010

3180 Walter Krämer and Gerhard Arminger, “True Believers” or Numerical Terrorism at the Nuclear Power Plant, September 2010

3181 Bernard M.S. Van Praag, Dmitri Romanov and Ada Ferrer-i-Carbonell, Happiness and Financial Satisfaction in Israel. Effects of Religiosity, Ethnicity, and War, September 2010

3182 Dimitrios Koumparoulis and Paul De Grauwe, Public Capital, Employment and Productivity: An Empirical Investigation for Greece, September 2010 
3183 John Whalley and Tanmaya Shekhar, The Rapidly Deepening India-China Economic Relationship, September 2010

3184 Andreas Schäfer and Thomas Steger, History, Expectations, and Public Policy: Economic Development in Eastern Germany, September 2010

3185 Thomas Eichner and Marco Runkel, Subsidizing Renewable Energy under Capital Mobility, September 2010

3186 Konstantinos Angelopoulos and James Malley, Fear of Model Misspecification and the Robustness Premium, September 2010

3187 Philip E. Graves, A Note on the Design of Experiments Involving Public Goods, September 2010

3188 Glenn Ellison, How does the Market Use Citation Data? The Hirsch Index in Economics, September 2010

3189 Barbara Hanel and Regina T. Riphahn, The Employment of Mothers - Recent Developments and their Determinants in East and West Germany, September 2010

3190 Alexander Haupt and Silke Uebelmesser, Integration, Mobility, and Human Capital Formation, September 2010

3191 Vincenzo Galasso and Paola Profeta, When the State Mirrors the Family: The Design of Pension Systems, September 2010

3192 Stéphane Zuber and Geir B. Asheim, Justifying Social Discounting: The RankDiscounted Utilitarian Approach, September 2010

3193 Alexander Kemnitz, Educational Federalism and the Quality Effects of Tuition Fees, September 2010

3194 Claudia M. Buch, Sandra Eickmeier and Esteban Prieto, Macroeconomic Factors and Micro-Level Bank Risk, September 2010

3195 May Elsayyad and Kai A. Konrad, Fighting Multiple Tax Havens, September 2010

3196 Laszlo Goerke and Markus Pannenberg, Trade Union Membership and Dismissals, September 2010

3197 Ferdinand Mittermaier and Johannes Rincke, Do Countries Compensate Firms for International Wage Differentials?, September 2010

3198 John Boyd, Gianni De Nicoló and Abu M. Jalal, Bank Competition, Asset Allocations and Risk of Failure: An Empirical Investigation, September 2010

3199 Guido Heineck and Bernd Süssmuth, A Different Look at Lenin’s Legacy: Trust, Risk, Fairness and Cooperativeness in the two Germanies, September 2010 
3200 Ingvild Almås, Tarjei Havnes and Magne Mogstad, Baby Booming Inequality? Demographic Change and Earnings Inequality in Norway, 1967-2000, October 2010

3201 Thomas Aronsson and Sören Blomquist, The Standard Deviation of Life-Length, Retirement Incentives, and Optimal Pension Design, October 2010

3202 Thorvaldur Gylfason and Eduard Hochreiter, Growing Together: Croatia and Latvia, October 2010

3203 Ken Burdett and Melvyn Coles, Tenure and Experience Effects on Wages: A Theory, October 2010

3204 Wendy Carlin, Good Institutions are not enough: Ongoing Challenges of East German Development, October 2010

3205 Tobias König and Andreas Wagener, Tax Structure and Government Expenditures under Tax Equity Norms, October 2010

3206 Daniel W. Sacks, Betsey Stevenson and Justin Wolfers, Subjective Well-Being, Income, Economic Development and Growth, October 2010

3207 Mario Larch and Wolfgang Lechthaler, Why "Buy American” is a Bad Idea but Politicians still Like it, October 2010

3208 Guglielmo Maria Caporale and Luis A. Gil-Alana, US Disposable Personal Income and Housing Price Index: A Fractional Integration Analysis, October 2010

3209 Bruno S. Frey, Withering Academia?, October 2010

3210 Eva Mörk, Anna Sjögren and Helena Svaleryd, Childcare Costs and the Demand for Children - Evidence from a Nationwide Reform, October 2010

3211 Dan Kovenock, Brian Roberson and Roman M. Sheremeta, The Attack and Defense of Weakest-Link Networks, October 2010

3212 Shmuel Nitzan and Kaoru Ueda, Prize Sharing in Collective Contests, October 2010

3213 Erling Eide, Kristine von Simson and Steinar Strøm, Rank Dependent Utility, Tax Evasion and Labor Supply, October 2010

3214 Thomas Eichner and Marco Runkel, Interjurisdictional Spillovers, Decentralized Policymaking and the Elasticity of Capital Supply, October 2010 